\title{
Integrating Insect, Resistance, and Floral Resource Management in Weed Control Decision-Making
}

\author{
Antonio DiTommaso, Kristine M. Averill, Michael P. Hoffmann, Jeffrey R. Fuchsberg, \\ and John E. Losey*
}

Managing agricultural pests with an incomplete understanding of the impacts that tactics have on crops, pests, and other organisms poses risks for loss of short-term profits and longer-term negative impacts, such as evolved resistance and nontarget effects. This is especially relevant for the management of weeds that are viewed almost exclusively as major impediments to crop production. Seldom considered in weed management are the benefits weeds provide in agroecosystems, which should be considered for optimal decision-making. Integration of weed costs and benefits will become increasingly important as management for pests transitions away from nearly complete reliance on herbicides and transgenic crop traits as the predominant approach for control. Here, we introduce a weed-management decision framework that accounts for weed benefits and exemplify how in-crop weed occurrence can increase crop yields in which a highly damaging insect also occurs. We highlight a case study showing how management decision-making for common milkweed, which is currently controlled primarily with glyphosate in herbicide-tolerant corn, can be improved by integrating management of the European corn borer (ECB), which is currently controlled primarily by the transgenic toxin Cry1 in Bacillus thuringiensis corn. Our data reveal that milkweed plants harboring aphids provide a food source (honeydew) for parasitoid wasps, which attack ECB eggs. Especially at high ECB population densities $\left(>1\right.$ egg mass leaf $\left.{ }^{-1}\right)$, maintaining low milkweed densities $\left(<1\right.$ stem $\left.\mathrm{m}^{-2}\right)$, effectively helps to minimize yield losses from ECB and to increase the economic injury level of this aggressive perennial weed. In addition, milkweed is the host for the monarch butterfly, so breeding-ground occurrences of the plant, including crop fields, may help sustain populations of this iconic insect. Using a more-holistic approach to integrate the management of multiple crop pests has the capacity to improve decision-making at the field scale, which can improve outcomes at the landscape scale.

Nomenclature: $\mathrm{Bt}$, Bacillus thuringiensis Berliner; glyphosate; common milkweed, Asclepias syriaca L.; corn, Zea mays L.; European corn borer, Ostrinia nubilalis Hübner; milkweed aphids, Aphis asclepiadis Fitch, Aphis nerii Boyer de Fonscolome, and Myzocallis asclepiadis Monel; monarch butterfly, Danaus plexippus L.; Trichogramma wasp, Trichogramma ostriniae Peng and Chen

Key words: Economic injury level, integrated pest management, pest management decisionmaking, weed management.

Management decision-making is optimized when accurate estimates of the costs and benefits of all management options are available (Waterfield and Zilberman 2012). For weed management, the value of increased yields from the control of weed populations has been recognized for thousands of years (Bridges 1994). A vast amount of research has been directed toward quantifying the benefits of

\footnotetext{
DOI: 10.1614/WS-D-16-00052.1

* First and second authors: Professor and Research Associate, Section of Soil and Crop Sciences, School of Integrative Plant Science, Cornell University, Ithaca, NY 14853; third and fifth authors: Professor and Professor, Department of Entomology, Cornell University, Ithaca, NY 14853; fourth author: Director of Intellectual Property and Innovation Projects, Medical Center of the Americas Foundation, 201 E. Main Street, El Paso TX 79901. Corresponding author's E-mail: ad97@cornell.edu
}

weed management across a wide range of conditions (Appleby 2005; Timmons 1970; Zimdahl 2004). The primary focus of that research has been on quantification of yield losses averted through reduction of weed populations (Zimdahl 2004). Less, but significant, effort has been devoted to quantifying the value of reducing reservoirs of insect pests (Capinera 2005; Norris and Kogan 2000) and pathogens (Smith et al. 2011; Srinivasan et al. 2008).

Balanced against these benefits of weed control are the costs associated with taking action to reduce weed populations. The primary costs most often quantified include herbicides, labor and fuel requirements, and equipment depreciation (Kadrmas et al. 2003). The decision to take action to reduce a weed population is made by comparing the 
benefit of yield losses averted to the costs of management.

The above paradigm assumes that weeds have only a negative role, namely as competitor, relative to crop yields. Given this assumption, reducing weed population densities should generally increase yields. However, other studies have shown that weeds can actually contribute to crop yield increases (Jordan and Vatovec 2004; Ziska and Dukes 2010). These positive roles include effects on soil retention or quality and the behavior or composition of insect fauna. When weeds are present in fields before and after crops, they can function like a cover crop and reduce soil erosion, increase soil-nutrient cycling, increase soil organic matter, and enhance soil microfauna and mesofauna (Jordan and Vatovec 2004; Jordan et al. 2000; Sturz et al. 2001). When weeds are growing simultaneously with crops, they can camouflage the crop, making it less apparent to herbivorous pests (Capinera 2005), provide nectar or pollen for pollinators (Altieri et al. 2015), and provide nectar, pollen, alternate prey, or other resources for natural enemies of insect pests (Altieri et al. 1977; Zandstra and Motooka 1978). Beyond maximizing profit, some growers value the diversity that weeds and the fauna they support represent (Wilson et al. 2008). Counter to the current paradigm, reducing weed-population densities decreases these ecological benefits and adds to weed management costs.

Failure to account for the positive roles of weeds could lead to suboptimal weed management decisions, specifically, reducing weed populations when their benefits outweigh their drawbacks. Unfortunately, the benefits of weeds have seldom been quantified and, as far as we are aware, never quantitatively integrated into a decision-making framework for weed management. Here, we introduce a weed-management decision-support framework that accounts for the benefits of a weed and illustrate the utility of this approach with a case study of the multitrophic interactions between two pests, common milkweed and the ECB (Figure 1). Although many weeds can co-occur in crop fields, we propose this framework to address situations in which milkweed is the primary problem; nonetheless, similar arguments for the benefits of weeds (e.g., hosts for natural enemies) also can be made for other weed species. Note that, at this time, little decision-making occurs regarding milkweed management and the limited damage that results from ECB because both are currently managed in most corn fields using transgenic crop traits and herbi- cides (Fernandez-Cornejo et al. 2014). However, as we detail below, several factors (e.g., cost, potential for resistance, impact on nontarget species) point toward the advisability of transitioning away from the almost-total reliance on these singular pestmanagement strategies. We offer our framework as a tool to facilitate the use of more-holistic management strategies that integrate the management of multiple crop pests (Kogan 1998). Taking into account all potentially damaging species stands to increase yields, reduce growers costs associated with pest management, and reduce environmental and societal externalities associated with agricultural intensification (Gagic et al. 2016).

Milkweed as a Weed. Common milkweed is a rhizomatous perennial broadleaf plant with an extensive root system, stout erect stems, opposite leaves, a milky sap, and purplish/pink/white flowers clustered in umbel-shaped inflorescences. Milkweed can reproduce by seeds, which are wind-dispersed in late summer and fall; however, most plants emerge from root buds occurring on rhizomes (Bhowmik 1994). The species is native to central and eastern United States and Canada, where it occurs in upland, nonwetland sites, usually in well-drained soil (USDA, NRCS 2015). Milkweed is found along roadsides, fencerows, and river basins and in grain crops, hay fields, old-fields, and nurseries (Bhowmik 1994).

Milkweed is a concern for growers because it competes for resources with crops and results in yield losses in many grain crops, including corn (up to $10 \%$ reduction), soybean [Glycine $\max$ (L.) Merr.] (19\%), oats (Avena sativa L.) (26\%), sorghum [Sorghum bicolor (L.) Moench ssp. bicolor] (29\%), and wheat (Triticum aestivum L.) (47\%) (Cramer and Burnside 1982; Evetts and Burnside 1973; Yenish et al. 1997a). Milkweed is problematic in no-till and reduced-tillage agricultural systems and does not persist in frequently mowed or cultivated systems (Bhowmik 1994; Yenish et al. 1997b). Before the use of glyphosate to control milkweed, weed infestations were largest in corn and soybeans in Iowa, Nebraska, and Wisconsin (Bhowmik 1994). In 2016, corn and soybean were planted in 38.1 and 33.9 million ha, respectively, across the United States (USDA, NASS 2016), representing large land areas for potential milkweed infestation.

Milkweed occurred widely before the extensive use of glyphosate (Cramer and Burnside 1982) and was found at a density of about $11.7 \mathrm{~m}^{2} \mathrm{ha}^{-1}$ in Iowa corn and soybean fields in 1999 (Hartzler and 


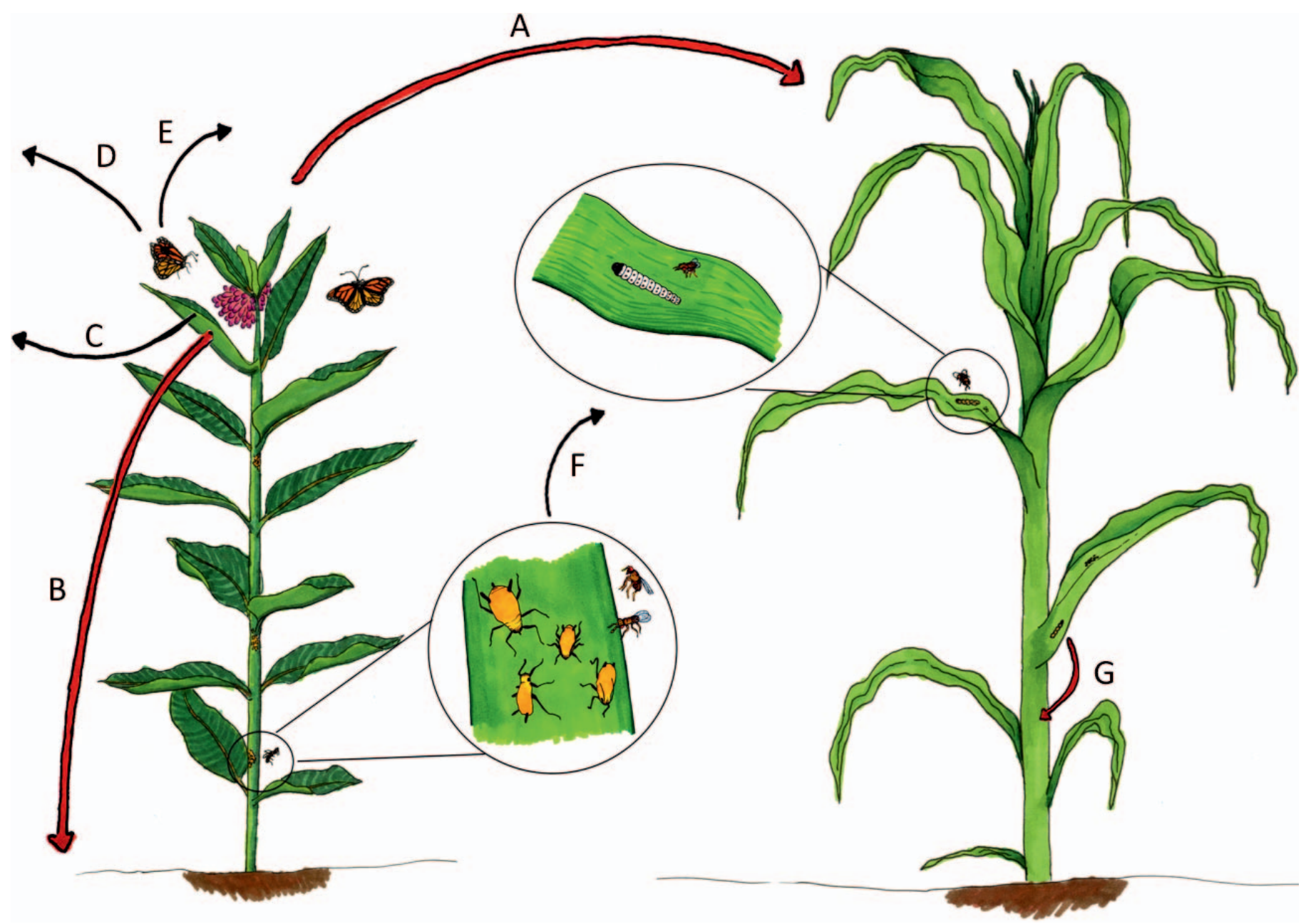

Figure 1. Ecological relationships among milkweed, corn, and insects relative to their impact on corn yield. Positive and negative effects of milkweed presence on corn yield are represented by thin and thick arrows respectively. Arrows extending to the boundary represent impacts beyond the focal field and season. (A) Milkweed competition with corn. (B) Milkweed contribution to seed/rhizome bank. (C) Probable herbicide-susceptible milkweed genes from untreated plants. (D) Monarchs contribute to population and decrease probability of federal protection and associated restrictions. (E) Monarchs (and other nontarget species) flourish on focal farm. (F) Trichogramma wasps (and other beneficial insects) benefit from honeydew produced by aphids and parasitize eggs of insect pests, such as the European corn borer. $(\mathrm{G})$ European corn borer eggs hatch and feed on maize stalks. (Color for this figure is available in the online version of this article.)

Buhler 2000; Pleasants 2015). In response to increasing glyphosate use, these populations rapidly declined in the early 2000s, so that, in 2009, the plant occurred at a density of only $0.4 \mathrm{~m}^{2} \mathrm{ha}^{-1}$, a $97 \%$ reduction of milkweed occurring within fields during the decade (Hartzler 2010; Pleasants 2015). In fields, as well as along roadsides across the Iowa landscape, milkweed occurrence declined by more than one-half between 1999 and 2009, raising concern for the host-specific monarch butterfly (Pleasants and Oberhauser 2012). Before the milkweed decline and based on the prevalence of milkweed in corn and high monarch survival in corn, it was estimated that 73 times more monarchs originate in corn compared with nonagricultural habitats (Oberhauser et al. 2001), and this reliance on corn is generally but not universally accepted (Inamine et al. 2016) (see "External Spatial and Temporal Impacts" below).

Despite declining milkweed populations, several trends in crop production indicate the importance of continued cognizance of the weed. For example, increasing weed resistance to glyphosate (Heap 2016) might instigate growers to use alternative herbicide programs that are less effective in controlling milkweed. Growers might also supplement their use of glyphosate with other herbicides. The use of glyphosate-resistance best-management practices (primarily using a diversity of herbicide active ingredients and modes of action), although more costly, stands to achieve comparable or increased crop yields attributable to improved weed 


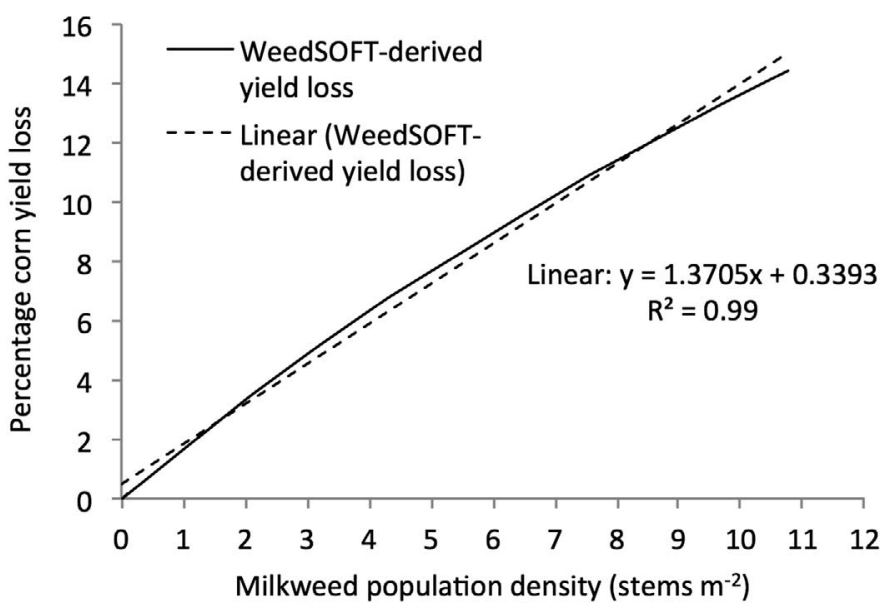

Figure 2. Relationship between milkweed population density and percentage corn yield loss based on WeedSOFT, a weed management decision-making aid (solid line), and a fitted linear relationship (dotted line). Note: this relationship is expected to vary based on soil, weather, and emergence periodicity (see text).

control in the short term, which helps offset increased weed-management costs (Edwards et al. 2014). Additionally, public criticism of, and increasing demand for, labeling of genetically engineered (GE) foods (Lucht 2015) could reduce production of glyphosate-tolerant crops, requiring readoption of pre-GE herbicide programs that might make milkweed control more challenging, depending on the crop (Lingenfelter and Curran 2015). The increasing adoption of organic no-till production could be accompanied by increases in perennial weeds, such as milkweed (Moyer 2011; Ryan et al. 2009). Additionally, growers might be willing to tolerate low milkweed population densities in favor of supporting the monarch butterfly. Milkweed populations are liable to rebound as biological, societal, and agronomic factors in crop production continue to evolve.

Milkweed Management. Control of milkweed was a more important management objective in corn production before the introduction of glyphosate. Data relating the degree of milkweed infestation to yield loss in corn are limited. In eastern Nebraska corn fields in the late 1970s, milkweed population densities ranging from 1.1 to 2.5 plants $\mathrm{m}^{-2}$ were associated with 9 to $15 \%$ stand losses and 2 to $10 \%$ yield losses (Cramer and Burnside 1982). These data imply that milkweed causes a $1 \%$ corn yield loss at a population density of 0.4 stems $\mathrm{m}^{-2}$. With average U.S. corn yields of $10.6 \mathrm{Mg} \mathrm{ha}^{-1}$ (168 bushels [bu] ac ${ }^{-1}$ ) and valued at $\$ 148 \mathrm{Mg}^{-1}$ (\$3.75 $\mathrm{bu}^{-1}$ ), as reported in 2015 (USDA, NASS 2016), a $1 \%$ yield loss to milkweed equates to an economic loss of $\$ 16 \mathrm{ha}^{-1}\left(\$ 6.3 \mathrm{ac}^{-1}\right)$. Using the weedmanagement decision-making tool WeedSOFT (Neeser et al. 2004), a similar milkweed population density-yield loss relationship is demonstrated. Based on a linear fit of the WeedSOFT output (Figure 2), a 1\% corn yield loss is associated with a milkweed population density of approximately 0.5 stems $\mathrm{m}^{-2}$. This is a simple model that does not account for location-specific soil, weather, or emergence periodicity encountered in the field, which can influence the relationship between weed density and crop yield loss (Lindquist et al. 1996, 1999).

Since the introduction of glyphosate-tolerant corn (Roundup Ready, Monsanto) in 1998, glyphosate (Weed Science Society of America Herbicide Group [HG] 9) has been an adequate (Beaton et al. 2015; Curran and Lingenfelter 2015; Jensen et al. 2015; Loux et al. 2016) and widely used chemical tool to control milkweed (Fernandez-Cornejo et al. 2014). However, several other herbicides can be used in milkweed management. For example, POST treatments of 2,4-D and dicamba (both HG 4) or both can be used to control milkweed in corn (Jensen et al. 2015; Loux et al. 2016) and can limit regrowth to 5 to $10 \%$ in the following season, providing effectiveness similar to glyphosate (see Bhowmik 1994 and references therein). Note that these growth-regulator herbicides are currently a control option in non-GE corn but not in non-GE soybean or cotton; however, with the recent deregulation of dicamba-tolerant crops by the U.S. Department of Agriculture (USDA, APHIS 2015), dicamba will likely soon be used in soybeans and cotton, which is liable to further reduce milkweed populations in the United States. Nonetheless, milkweed is expected to continue to occur and require management even if in smaller populations. Mesotrione (HG 27) (for glyphosate-tolerant hybrids only) and combinations of dicamba + diflufenzopyr (HG 19), dicamba + halosulfuron (HG 9), or dicamba + rimsulfuron (HG 9) + nicosulfuron (HG 9) also offer chemical control options for milkweed (Beaton et al. 2015; Curran and Lingenfelter 2015; Jensen et al. 2015).

Cultural control of milkweed can be achieved when a competitive crop, such as alfalfa (Medicago sativa L.), winter wheat, or a dense stand of other weeds, is established (Bhowmik 1994; Evetts and Burnside 1975). Mechanical control of milkweed in conservation-tillage systems results in fragmented rhizomes, which could increase the number of plants and contribute to their spread (Bhowmik 1994). However, fields in which conventional tillage 
is used have lower milkweed population densities than do fields where conservation tillage is used (Yenish et al. 1997b), and seedling emergence from seed buried at a soil depth of $7 \mathrm{~cm}$ is negligible (Yenish et al. 1996). Additionally, in organic graincrop production, tillage has been used as a dependable tool to manage perennial weeds, including milkweed (Ryan et al. 2010). Depending on any one pest-control tactic increases the liability of evolving resistance, whereas integrating multiple management tactics and using ecological interactions can effectively suppress weeds, often with less reliance on herbicides (Palumbi 2001; Westerman et al. 2005).

\section{European Corn Borer as an Insect Pest in Corn.} Similar to most major crops, insect pests, in addition to weeds, reduce corn yields. The ECB is one insect pest of corn for which the interaction of insects and milkweed could be important. The billion dollars of annual losses caused by ECB (Hutchison et al. 2010) and the difficulty of controlling an insect that spends most of its life cycle protected in plant stems drove considerable effort to develop effective, classical, biological control (Bartlett and Clausen 1978; Mason et al. 1996). However, despite successful natural enemy establishment and substantial effects, the level of suppression from ambient levels of naturally occurring and introduced natural enemies was often inadequate to prevent economic losses to this pest (Wressell 1973). The incomplete control of ECB with insecticides made it an initial target of transgenic corn in the United States. Genetically engineered corn with Bt and the Cryl toxins very effectively controls this pest and was registered in 1996 (Shelton et al. 2002). Corn hybrids expressing the Cryl toxin are often "stacked" with genes expressing the Cry3 toxin (targeting corn rootworm, Diabrotica spp.) and herbicide tolerance. In 2015, crops with both $\mathrm{Bt}$ and herbicide-tolerance traits accounted for $77 \%$ of all field corn planted in the United States (USDA, NASS 2015). However, several factors indicate that this level of reliance on a single tactic may decrease in the near future (Mortensen et al. 2012; Shaner et al. 2012), creating a need for alternate strategies. One reason why some corn growers might currently prefer to not purchase hybrids expressing the Cryl toxin with their associated costs is that these hybrids have become victims of their own success. The toxin is so effective at killing ECB larvae and the level of adoption so high that ECB population densities declined across the Midwest, leading to increased demand for cheaper "non Cry1" hybrids that have favorable agronomic traits from growers who think the $\mathrm{Bt}$ protection is no longer necessary (Hutchison et al. 2010). In recent years, GE corn is increasingly more costly compared with non-GE corn (Osteen et al. 2012). Additional factors that could lead to a higher proportion of corn being planted to nonCry1 hybrids in the future are the development of ECB populations that are resistant to this toxin (Siegfried and Hellmich 2012) and an increase in market demand for non-GMO crops (Lucht 2015). Thus, it would be prudent to develop alternatives for ECB control now before Cryl hybrids lose effectiveness and to support emerging markets.

Milkweed and Insect Interactions in Corn. Relationship of Milkweed, Aphids, and Parasitoids. Although milkweed can have a negative effect on corn yield through competition, it can also have a positive, indirect effect on yield by providing resources used by natural enemies of herbivorous pest insects (Figure 1). Although the exact components and concentrations vary, plants in the milkweed family generally have effective chemical defenses. The herbivorous insect community on milkweed includes only 12 species in eastern North America (Smith et al. 2008). We focus here on the three aphids (Hemiptera: Aphididae) that feed on milkweed: $A$. asclepiadis (Fitch), A. nerii (Boyer de Fonscolome), and $M$. asclepiadis (Monel) (Smith et al. 2008), and for the purposes of this study, we group them as "milkweed aphids." In corn, similar to other systems, aphids function at several trophic levels, serving as prey for predators, such as lady beetles (Coleoptera: Coccinellidae) (Stephens et al. 2012) and, most pertinent to our study, they are one of the 10 insect families (8 Hemiptera and 2 Lepidoptera) that feed primarily on photosynthate and produce a sugary waste liquid known as honeydew (Lundgren 2009). This honeydew can be an important source of nutrition for Hymenopteran insects, such as ants and wasps (Lundgren 2009), including parasitoids, such as Trichogramma wasps that have key roles in biological control (Faria et al. 2007).

Honeydew as a Source of Nutrition for Trichogramma Wasps. One group of wasps that is known to feed on and benefit from aphid honeydew are the Trichogramma (Hymenoptera: Trichogrammatidae) (Fuchsberg et al. 2007). Trichogramma wasps are minute egg parasitoids that are among the most widely augmented biological control agents released on millions of hectares each year (Li 1994; Smith 


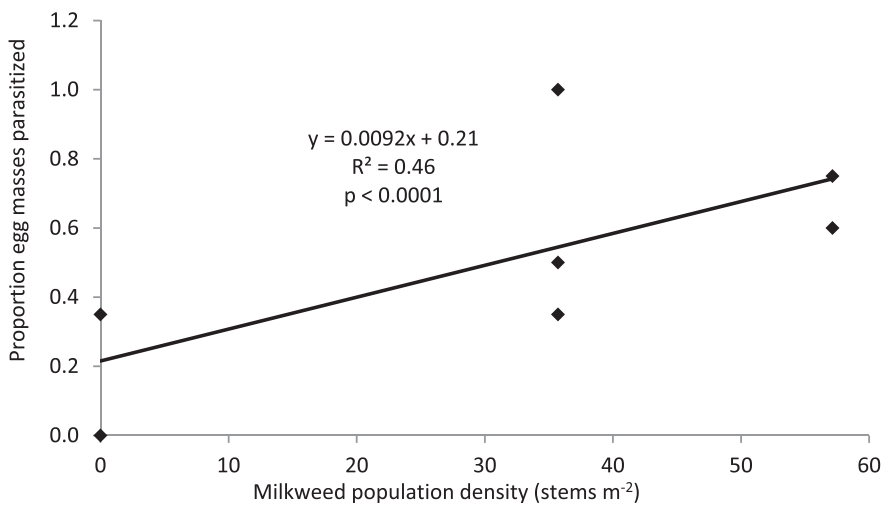

Figure 3. Relationship between milkweed population density and the proportion of European corn borer egg masses parasitized. Significance based on logistic regression.

1996; Zhang 2010). By parasitizing egg masses, ambient populations of Trichogramma wasps can exert substantial control of ECB populations (Hoffmann et al. 2006). Trichogramma ostriniae, a species imported into North America from China in the early 1990s, shows particular promise for ECB control (Fuchsberg et al. 2007). Trichogramma ostriniae exhibited increased longevity and fecundity when they were provided with honey (Hoffmann et al. 1995), and the same effect was subsequently reported with aphid honeydew (Fuchsberg et al. 2007). Although Trichogramma wasps are not widely released to control ECB in field corn in the United States, Hoffmann et al. (2006) reviewed the successful reduction of ECB in sweet corn and reported the reduction of ECB in field corn in 2001 and 2002 (Hoffmann et al. 2002). In addition, as we describe above, an increasing proportion of growers may seek alternatives to $\mathrm{Bt}$-corn for ECB management so augmentation of Trichogramma could be adopted more widely.

Although the potential effect of a sugar source enhancing parasitism by Trichogramma wasps was not addressed in Hoffmann et al. (2006), a positive effect of nectar has been reported in cotton (Gossypium spp.), from extrafloral nectaries (Treacy et al. 1987) and with buckwheat (Fagopyrum esculentum Moench), as the nectar source in both grape (Vitis spp.) (Nagarkatti et al. 2003) and bell peppers (Capsicum annuum L.) (Russell and Bessin 2009; Sarajlić et al. 2014). From these studies, sugar sources can significantly facilitate parasitism by Trichogramma wasps in the field as well as the laboratory.

Field Test of Milkweed Aphid Facilitation of Parasitism by Trichogramma Wasps. One aspect of the data from the 2001 to 2002 field study that was

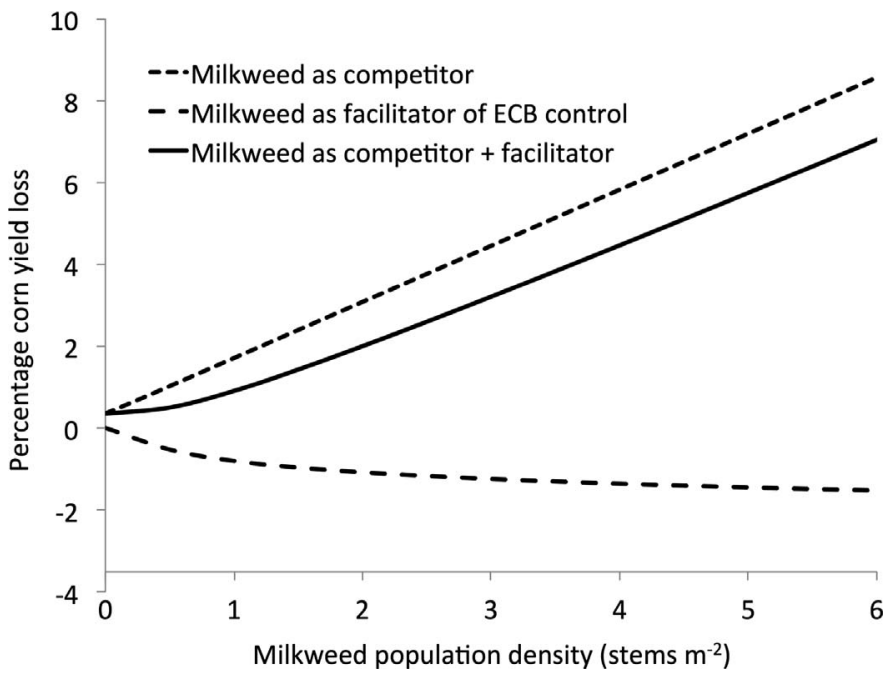

Figure 4. Corn yield losses accrued from a range of milkweed population densities considering milkweed as a competitor, as a facilitator of European corn borer (ECB) control, and with both roles combined. The ECB relationship is based on an initial density of 0.3 egg-masses plant ${ }^{-1}, 11.36$ larvae egg-mass $^{-1}$ (Iowa State University 2013), and a 5.94\% yield-loss larvae ${ }^{-1}$ plant $^{-1}$ (Bode and Calvin 1990).

recorded but not reported in Hoffmann et al. (2006) was the population density of milkweed stems. These data were recorded because the relationship between honeydew and $T$. ostriniae had previously been established (Fuchsberg et al. 2007), and milkweed plants within the field study area were known to commonly support high aphid population densities. Methods, including those for assessment of parasitism of ECB egg masses, follow details in Hoffmann et al. (2006), with the addition of an assessment of milkweed population (stem) density using standard methods (Caldwell et al. 2014; Mohler et al. 2016). The result was a significant, positive relationship between the population density of milkweed stems and the parasitism of ECB egg masses $(\mathrm{P}<0.0001$; analyzed with logistic regression) (Figure 3). Although in that study, infestation of aphids on milkweed was high and infestation on corn stalks was very low, in some years, the corn leaf aphid Rhopalosiphum maidis Fitch can be present in substantial densities (Curran and Lingenfelter 2015).

Implications of Biological Control Facilitation for Milkweed Management in Corn. The implication of a positive relationship between milkweed population density and ECB parasitism is that increased milkweed population density can, under certain conditions, reduce losses from damage by ECB feeding (Figure 4). As noted above, if we consider milkweed as only a competitor (e.g., not a resource 


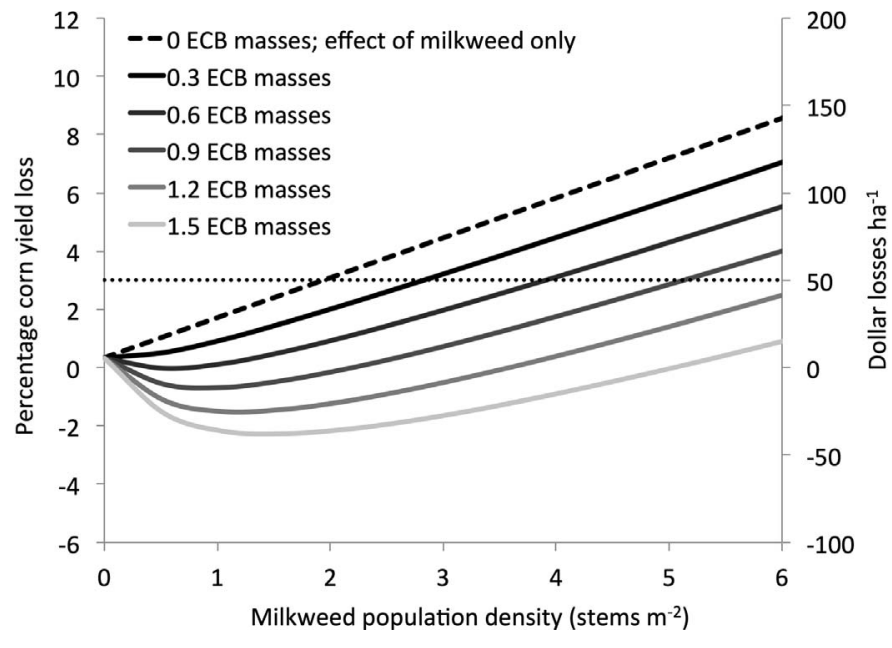

Figure 5. Viewing milkweed as both a weed and a facilitator of European corn borer (ECB) control, the relationship between corn yield loss and milkweed population density depends on the density of ECB egg masses per leaf. ECB relationship based on 11.36 larvae egg-mass $^{-1}$ (Iowa State University 2013) and a $5.94 \%$ yield-loss larvae plant $^{-1}$ (Bode and Calvin 1990). Associated dollars lost are based on the value of corn at $\$ 1,560.47 \mathrm{ha}^{-1}$ (using the 2015 U.S. average yield of $168.4 \mathrm{bu}$ $\mathrm{ac}^{-1}$ and price received of $\$ 3.75 \mathrm{bu}^{-1}$ ) (USDA, NASS 2016). The dotted line shows the cost of milkweed control, $\$ 50.04 \mathrm{ha}^{-1}$ (D Lingenfelter, personal communication); the economic injury levels occur where the dotted line intersects the curves.

providing honeydew for parasitoids), then losses rise with increasing milkweed population density as competition becomes more intense (Figure 4). However, it should be clear that milkweed has both the roles of competitor and pest-suppression facilitator, so the effect of both roles should be summed to find the total impact of milkweed in corn (Figure 4). We calculated the combined loss curves by generating values for losses from milkweed (Figure 4; milkweed as competitor) and losses from ECB (Figure 4; milkweed as a facilitator of ECB control) across a range of milkweed densities and then summing the values at each density (Figure 4; milkweed as competitor + facilitator). The losses from competition alone are modeled as linear across milkweed densities, whereas the curve value as a facilitator and the resulting combined curve both have higher-order shapes because of the upper limit of honeydew facilitation.

Although we could not quantify it here, the value of aphids on milkweed would be less if there were aphids supplying honeydew on the corn itself (e.g., corn leaf aphids) because herbicide treatments would not affect the aphids on corn (Curran and Lingenfelter 2015). Conversely, application of glyphosate would reduce not only milkweed but also other weeds, and $97 \%$ of vascular plants species support aphid populations (Dixon et al. 1987). Options are available for species-specific weed control in the case in which a grower needs to control weeds other than milkweed. For example, a graminicide, such as nicosulfuron, could be used to control weedy grasses without damaging corn or milkweed. Because weeds typically have patchy distributions, partial cultivation of a field might also be a feasible control strategy.

The value of the facilitation of milkweedmediated ECB suppression depends on the density of the insect pest. In the absence of ECB, the effect of milkweed on corn is reduced to competition only (Figure 5). The value of the facilitation increases as the initial population density of ECB egg masses increases (Figure 5). Each of these curves (Figure 5) represents a unique loss-density function $(D)$.

Incorporating Local Services into Weed-Management Decision-Making. Balancing the cost of milkweed as a corn competitor with its value as a resource for ECB parasitoids is an example of broader decision-making that can be applied to our example and beyond this system with a generalized formula. The standard formula for calculating an economic injury level (EIL) in units of pestpopulation density (e.g., weeds per square meter) or some index of population density (e.g., insects per trap) incorporates the cost of the specific control $(C)$, the value of the commodity being produced $(V)$, and the yield lost per unit of pest population density $(D)$ (Stern et al. 1959). The formula generally takes the following form:

$$
E I L=C / V D
$$

Using this formula, integrating any benefits that might accrue from increasing population density of the focal "pest" (e.g., milkweed) is fairly simple. If the benefits from increasing pest population density can be estimated and a combined function $\left(D_{i}\right)$ can be calculated, as in our example with milkweed facilitating ECB control, then the formula for the integrated EIL becomes the following:

$$
E I L_{i}=C / V D_{i}
$$

Note that this formula is flexible in the sense that if $D_{i}<D$, as in our example, then, $E I L_{i}>E I L$, but if $D_{i}>D$, such as might be the case if a weed had a negative effect on a beneficial insect in addition to competition with the crop, then $E I L_{i}<E I L$. We encourage future authors to refine the model to account for location-specific soil, weather, and crop and weed emergence periodicity, which can affect

DiTommaso et al.: Integration of pest control • 
Table 1. Milkweed economic injury level (EIL) in corn across varying levels of initial European corn borer (ECB) egg mass population density.

\begin{tabular}{lc}
\hline ECB & Milkweed EIL \\
\hline masses plant $^{-1}$ & stems $\mathrm{m}^{-2}$ \\
0 & 2.1 \\
0.3 & 3.0 \\
0.6 & 4.2 \\
0.9 & 5.4 \\
1.2 & 6.6 \\
1.5 & 7.9 \\
\hline
\end{tabular}

the weed density-crop yield loss relationship (Lindquist et al. 1996, 1999).

Accounting for Both Negative and Positive Effects of Milkweed. With the new loss-pest density (D) relationships reflecting both effects, calculating a series of EILs is straightforward (following Stern et al. 1959) (Table 1). We analyzed the combined curves at each ECB density by regressing the summed loss on milkweed density (SAS 2012). With no ECB present, the EIL for milkweed is based only on balancing the cost of treating with an herbicide with the losses averted by decreasing competition, yielding a linear $D$ relationship with no significant second- or third-order component $(\mathrm{P}>0.05)$. As the initial ECB population density increases, the value of milkweed, in terms of the role it has in averting losses from the larvae, also increases, and thus, the $D$ relationship diverged from the linear-competition curve and included significant second- and third-order components ( $\mathrm{P}<0.05$ for all nonzero values of ECB evaluated). Using constant values for $C\left(\$ 50.04 \mathrm{ha}^{-1}\right)$ (D Lingenfelter, personal communication) and $V$ $\left(\$ 1,560.47 \mathrm{ha}^{-1}\right)$ (USDA, NASS 2016), the decreasing values for $D$ lead to a higher EIL for milkweed (Table 1). With very high initial ECB densities (e.g., 1.5 plant $^{-1}$ ), even where milkweed represents a substantial value for ECB suppression, milkweed competition can be so intense that associated yield losses exceed the combined costs of management and the value of enhanced larval suppression. The use of insecticides to suppress ECB populations, thus reducing the beneficial value of milkweeds and making it profitable to control milkweed at lower densities, is theoretically possible but not actually feasible for two reasons. First, any insecticide used would have a cost and that cost would balance against the losses averted by maintaining milkweeds at a lower density. Second, because ECB bore into the stalk where they are

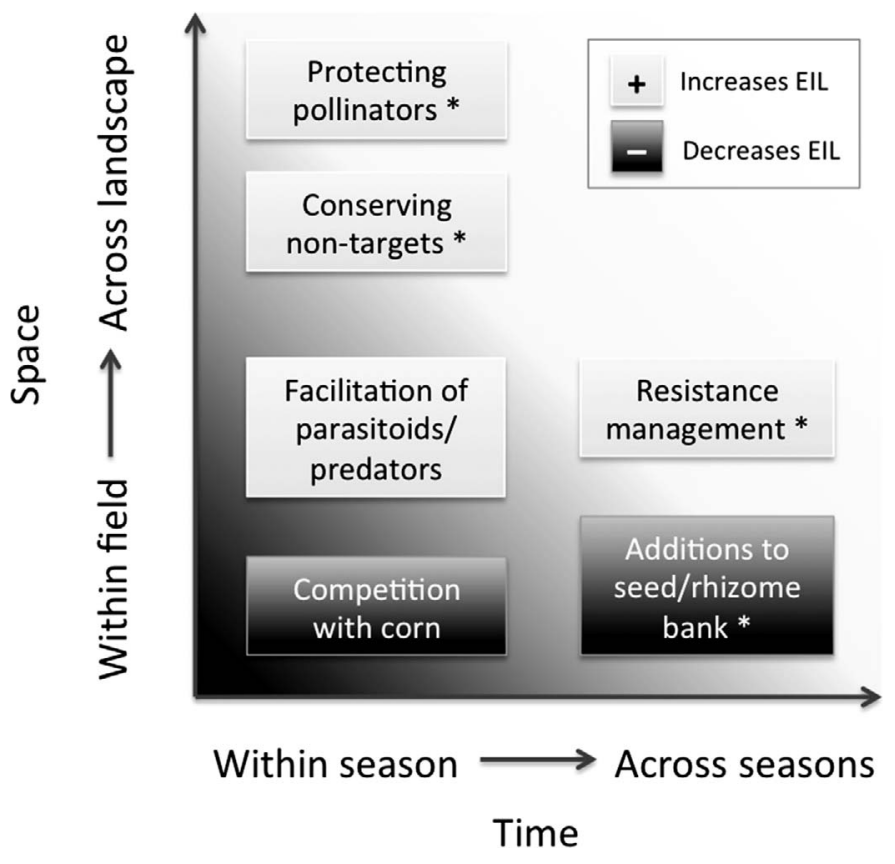

Figure 6. Effects of milkweed in the corn agroecosystem as they relate to the relative impact on the economic injury level (EIL). *No data available.

protected after just two instars, the window to control larvae is very small and is often difficult to pinpoint. In addition, the primary damage occurs in the second generation when the plants are so tall that most growers do not have equipment to spray without damaging the corn plants. A low proportion of growers were ever able to control ECB with spray insecticides, which is why the pest became a target for biological control and host-plant resistance, including transgenic Bt corn. In summary, management decisions differ substantially when all of the ecological roles of a plant are considered.

External Spatial and Temporal Impacts. The positive effect of milkweed reducing losses from ECB is indirect via aphids and parasitoids, but the effect is quantifiable, and it takes place within the field and season for which the management decision is being made and, thus, is "internal" to the temporal and spatial scale of the decision. Impacts that take effect in a temporal or spatial frame external to the focal field and season, termed externalities (Pretty et al. 2000), are usually more difficult to quantify (Figure 6). In general, the farther the effect is from the focal field and season, the more difficult the externality is to quantify. The contribution of weeds to the future weed-population density through the seedbank (including rhizomes) is an example of an externality that is within the focal field and often not far removed 
temporally. For some weeds, including milkweed, this contribution to higher population densities can take effect within the same season via new shoots emerging from rhizomes (Bhowmik 1994), so such weeds would have both internal and external effects. There have been many assessments of the "external" consequences of weed-management decisions on seedbanks in future years (e.g., Buhler et al. 1997; Burnside et al. 1986; Davis et al. 2005; Gallandt 2006). Some weed seeds persist in the seedbank for many decades (e.g., velvetleaf, Abutilon theophrasti Medik.) (Warwick and Black 1988), which makes determining the impacts of their management challenging to quantify.

An externality of weed-management decisions further removed than seedbanks is the evolution of resistance to control tactics, with herbicide resistance being particularly challenging. The impacts of selection for herbicide resistance often take longer than seedbanks to affect yields and profits because they typically takes many generations for resistance to evolve (Nalewaja 1999), although for some weed species (e.g., rigid ryegrass, Lolium rigidum Gaudin) and herbicide compounds (e.g., sulfonylureas) resistance development can occur more quickly (Preston and Powles 2002). Although herbicide resistance can affect the field in which selection occurs, incorporation into modeling is complicated because the effects of, and selection for, herbicide resistance are dependent on actions taken outside the focal field and season (e.g., management decisions of other growers affecting weed propagule supply). Resistance management for herbicides includes practices such as crop rotation, herbicide active-ingredient rotation, and integration of weedcontrol tactics (Prather et al. 2000). Resistance management has become a key component of pest management decision-making (Prather et al. 2000), but weed resistance to herbicides continues to be a major and increasing issue (Shaner et al. 2012; Vencill et al. 2012).

Even further removed from the focal field and season are potential weed-management effects on pollinators and other nontarget species considered common-pool resources. Native insect pollinators are known to be extremely important for agricultural production, and the service they provide has been shown to add $\$ 3$ billion to the U.S. economy each year (Losey and Vaughan 2006). The most obvious connection between weed management and pollination is in commodities that depend on insect pollination, such as most fruits and vegetables. Weed management affects pollinators via direct exposure of the beneficial insects to herbicides (Herbert et al. 2014) or indirectly through the loss of nectar resources (Bohnenblust et al. 2016; Egan et al. 2014) and habitat (Altieri et al. 2015). Integrating control of pests in these systems, along with the facilitation of pollinators, is an acknowledged need (e.g., in apples, Malus Mill.; Biddinger and Rajotte 2015), and recent reports provide impetus for the integration of plant-pathogen management and pollinator facilitation (Park et al. 2015). The value of supporting pollinators is immediate and local in insect-pollinated crops, but even in cropping systems that do not depend directly on pollination for production (e.g., most grain and forage crops), enhanced pollination in other areas of the farm or region is valuable (Altieri et al. 2015; Bretagnolle and Gaba 2015).

Although the benefits of seedbank and herbicideresistance management and pollinator facilitation usually are accrued outside the focal season and field, they represent a tangible value (although not necessarily quantified) to the individual grower (Figure 1). In contrast, some management practices have a neutral or negative effect on profit, but growers choose them willingly because they represent a value beyond monetary profit, e.g., minimizing negative effects on, or having a positive effect on, societal or environmental goals (Wilson et al. 2008). Among environmental goals, the most common is a desire to minimize the effect of pest management on species that are neutral in terms of their impact on yield (e.g., wildlife or insects; Wilson et al. 2008). Many growers are willing to modify the management of their crops in ways that decrease profits if they perceive that such modifications minimize negative effects on nontarget species (Greiner 2015). Assuming that growers' attitudes are similar to those of the public, the amount of profit that individual growers might be willing to eschew has been quantified as "willingness to pay" (Diffendorfer et al. 2014).

The potential to affect neutral, nontarget species during the course of weed management in corn is broad. Losey et al. (2003) estimated that 132 plant species and 229 Lepidopteran species feeding on them occur in and around corn fields. This list includes species that potentially have a quantifiable effect on profit, but most of them likely do not affect profit. Undoubtedly, the best-known, iconic or "flagship" of these species is the monarch butterfly.

The monarch butterfly is arguably one of the most popular insects in North America. The

DiTommaso et al.: Integration of pest control • 751 
monarch was named the national insect of the United States in 1990, and it is also the insect symbol of 7 of the 50 states (State Symbols USA 2016). Unfortunately, this species is undergoing a steep decline. Although a 2015 monarch survey suggested a rebound from recent years, their numbers are still well below the historic average (World Wildlife Fund 2016). Pleasants and Oberhauser (2012) report an 81\% decline in monarch numbers from 1999 to 2010, and they attribute this loss to a $58 \%$ decline in the abundance of milkweed, the sole food of monarchs, in the midwestern United States. They suggest that this decline in milkweed is due to the rise in the adoption of herbicide-tolerant crops and the associated use of glyphosate on a large proportion of corn and soybean acreage (Pleasants and Oberhauser 2012). In response to the linkage between monarch butterfly decline and glyphosate-tolerant weeds, Monsanto has initiated a monarch butterfly conservation program (Monsanto 2015). A recent study supports that the primary driving factor in monarch decline is the reduction in milkweed population densities in the Midwest and not climate change or degradation of overwintering habitats in Mexico (Flockhart et al. 2015); however, not all studies agree on the level of effect the reduction in milkweed has on monarch populations (Howard and Davis 2015; Inamine et al. 2016; Pleasants et al. 2016; Semmens et al. 2016).

In 2014, the U.S. Fish and Wildlife Service (USFWS) found sufficient evidence to warrant consideration of the monarch butterfly for protection under the Endangered Species Act (USDI 2014). Although a final ruling on the listing will take some time, the USFWS has already allocated $\$ 3.2$ million for monarch conservation (Lee 2015). However, these efforts are primarily focused on planting milkweed in "reserves" of varying sizes, and some analyses indicate this strategy will be insufficient to offset the loss of milkweed from crop fields (Flockhart et al. 2015). This is especially relevant because it has been estimated that $56 \%$ of monarch butterflies breed on within-corn field populations of milkweed, and this estimate is more than $90 \%$ if soybean fields are included (Oberhauser et al. 2001).

Although the popularity and plight of monarch butterflies are clear, the implications for weedmanagement decision-making are less straightforward. If government conservation programs existed to offer money to growers to refrain from controlling milkweed, similar to that offered to land managers in Mexico who refrain from degrading the monarch's overwintering habitat (Honey-Rosés 2009), then those incentives could be factored in to the EIL equation. Evidence indicates that incentives to private landowners can be effective for facilitating the conservation of endangered or threatened species, and some incentives are more cost effective than others (Drechsler et al. 2016; Langpap 2006).

In the absence of conservation incentives, the only monetary value that milkweed possesses in its role as food for monarchs is the value that growers individually assign to it. Diffendorfer et al. (2014) reported that respondent U.S. households would be willing to make a one-time payment of between $\$ 54$ and $\$ 74$ to conserve monarchs. That amount does not necessarily reflect the amount of profit that growers would be willing to eschew on an annual basis to conserve monarchs, but it implies that they would be willing to incur some level of financial loss to conserve the iconic insects, assuming grower attitudes reflect those of the public.

Beyond potential incentives and willingness to pay for conservation, the possible listing of the monarch butterfly under the Endangered Species Act provides another conceivable motivation for growers to modify their decision-making regarding the management of the monarch's sole food, milkweed. Listing a species as threatened or endangered means potentially severe restrictions in management options. Not only would monarch "take" (e.g., collection) be prohibited, but degrading the monarch's critical habitat could also result in fines of up to $\$ 50,000$ and up to $1 \mathrm{yr}$ in prison (Yarrow 2009). The threat of these restrictions would appear to offer substantial motivation for growers to cooperate with conservation efforts now to prevent the species from ever needing to be put onto the list. This type of cooperative effort was a remarkable success in the case of the greater sagegrouse (Centrocercus urophasianus Bonaparte), which was proposed but not listed (USDI 2015), and an attempt to organize a similar cooperative effort for monarch butterflies is in progress (Holst 2016). Growers who wish to avoid the restrictions associated with the monarch being listed as endangered could raise their EIL for milkweed to reflect the additional value of this plant as protection against restrictions (Figure 1).

Many externalities could be integrated into weedmanagement decision-making. In the specific case of incorporating the value of milkweed-facilitating parasitoids, we developed a relationship that varied 
across milkweed and ECB population densities, allowing us to modify the EIL formula by varying the pest population density parameter $D_{i}$. This method will most likely not be possible for most external factors with less-quantitative data available. A simpler method would be to incorporate single values for the costs $(C)$ or benefits $(B)$ that each externality imparts on weed control. All costs and benefits could then be summed and included in the EIL calculation:

$$
E I L=\left(\sum C_{i}-\sum B_{i}\right) / V D
$$

Using this formula, each additional cost (e.g., herbicide costs) would drive the EIL up, as in the conventional application of this formula. More complex is the application to benefits. Each benefit represents a potential value that will be lost if the pest population (e.g., milkweeds) is reduced. For example, if growers valued monarchs on their farm at a value of $X$, then (if controlling milkweeds eliminated monarchs) the value to insert into Equation 3 would be negative $(-X)$. Thus, each additional cost and each additional lost benefit would both drive the EIL up. In a qualitative sense, as the sum of costs associated with treatment and the benefits lost because of treatment increase, a higher density of pests would be required to justify the management action.

These factors beyond direct competition from weeds may seem minor, especially for individual growers, but in the aggregate, they can have substantial long-range consequences. Failing to integrate the full costs and benefits of weed management can lead to "black swan" events, i.e., negative phenomena that are unexpected but could have been predicted with a wider view of the problem (Taleb 2007), such as the resistance to glyphosate and declining monarch populations that have emerged from widespread adoption of herbicide-tolerant crops. Full integration of all costs and benefits offers the greatest opportunity for longterm weed management and sustains profitability while minimizing negative environmental impacts.

\section{Acknowledgments}

The authors would like to thank Anurag Agrawal, Michael Owen, and Matthew Ryan for helpful suggestions on earlier versions of the manuscript. We thank Olivia McCandless for creating the illustration included in Figure 1. We thank two anonymous reviewers whose comments and sugges- tions improved this work. A special thank you to Quincy Ryan for inspiring us to complete this work.

\section{Literature Cited}

Altieri MA, Nicholls CI, Gillespie M, Waterhouse B, Wratten S, Gbéhounou G, Gemmill-Herren B (2015) Crops, Weeds and Pollinators: Understanding Ecological Interactions for Better Management. Rome, Italy: Food and Agriculture Organization of the United Nations. $96 \mathrm{p}$

Altieri MA, Van Schoonhoven A, Doll J (1977) The ecological role of weeds in insect pest management systems: a review illustrated by bean (Phaseolus vulgaris) cropping systems. PANS Pest Artic News Summ 23:195-205

Appleby AP (2005) A history of weed control in the United States and Canada-a sequel. Weed Sci 53:762-768

Bartlett BR, Clausen CP (1978) Introduced Parasites and Predators of Arthropod Pests and Weeds: A World Review. Washington, DC: Agricultural Research Service, U.S. Dept. of Agriculture Agriculture Handbook 480.545 p

Beaton D, Obeid K, Chaput J, Cowbrough M (2015) Guide to Weed Control 2016-2017. Toronto, ON: Ontario Ministry of Agriculture, Food and Rural Affairs Publication 75. $468 \mathrm{p}$

Bhowmik PC (1994) Biology and control of common milkweed (Asclepias syriaca). Rev Weed Sci 6:227-250

Biddinger DJ, Rajotte EG (2015) Integrated pest and pollinator management-adding a new dimension to an accepted paradigm. Curr Opin Insect Sci 10:204-209

Bode WM, Calvin DD (1990) Yield-loss relationships and economic injury levels for European corn borer (Lepidoptera: Pyralidae) populations infesting Pennsylvania field corn. J Econ Entomol 83:1595-1603

Bohnenblust EW, Vaudo AD, Egan JF, Mortensen DA, Tooker JF (2016) Effects of the herbicide dicamba on nontarget plants and pollinator visitation. Environ Toxicol Chem 35:144-151

Bretagnolle V, Gaba S (2015) Weeds for bees? a review. Agron Sustain Dev 35:891-909

Bridges DC (1994) Impact of weeds on human endeavors. Weed Technol 8:392-395

Buhler DD, Hartzler RG, Forcella F (1997) Implications of weed seedbank dynamics to weed management. Weed Sci 45:329-336

Burnside OC, Wilson RG, Wicks GA, Roeth FW, Moomaw RS (1986) Weed seed decline and buildup in soils under various corn management systems across Nebraska. Agron J 78:451454

Caldwell BA, Mohler CL, Ketterings QM, DiTommaso A (2014) Yields and profitability during and after transition in organic grain cropping systems. Agron J 106:871-880

Capinera JL (2005) Relationships between insect pests and weeds: an evolutionary perspective. Weed Sci 53:892-901

Cramer GL, Burnside OC (1982) Distribution and interference of common milkweed (Asclepias syriaca) in Nebraska. Weed Sci 30:385-388

Curran WS, Lingenfelter D (2015) The Penn State Agronomy Guide 2015-2016. University Park, PA: The Pennsylvania State University

Davis AS, Renner KA, Gross KL (2005) Weed seedbank and community shifts in a long-term cropping systems experiment. Weed Sci 53:296-306

Diffendorfer JE, Loomis JB, Ries L, Oberhauser K, LopezHoffman L, Semmens D, Semmens B, Butterfield B, Bagstad

DiTommaso et al.: Integration of pest control • 753 
K, Goldstein J, Wiederholt R, Mattsson B, Thogmartin WE (2014) National valuation of monarch butterflies indicates an untapped potential for incentive-based conservation. Conserv Lett 7:253-262

Dixon, AFG, Kindlmann P, Lepš J, Holman J (1987) Why there are so few species of aphids, especially in the tropics. Am Nat 129:580-592

Drechsler M, Smith H, Sturm A, Wätzold F (2016) Payments for conservation measures to incentivize connected habitats: cost-effectiveness of agglomeration payments, agglomeration bonuses and spatially homogeneous payments in the presence of two endangered species. Conserv Biol. DOI: 10.1111/cobi. 12708

Edwards CB, Jordan DL, Owen MD, Dixon PM, Young BG, Wilson RG, Weller SC, Shaw DR (2014) Benchmark study on glyphosate-resistant crop systems in the United States. Economics of herbicide resistance management practices in a 5 year field-scale study. Pest Manag Sci 70:1924-1929

Egan JF, Bohnenblust E, Goslee S, Mortensen D, Tooker J (2014) Herbicide drift can affect plant and arthropod communities. Agric Ecosyst Environ 185:77-87

Evetts LL, Burnside OC (1973) Competition of common milkweed with sorghum. Agron J 65:931-932

Evetts LL, Burnside OC (1975) Effect of early competition on growth of common milkweed. Weed Sci 23:1-3

Faria CA, Wäckers FL, Pritchard J, Barrett DA, Turlings TC (2007) High susceptibility of Bt maize to aphids enhances the performance of parasitoids of Lepidopteran pests. PLoS One 2:e600

Fernandez-Cornejo J, Wechsler S, Livingston M, Mitchell L (2014) Genetically Engineered Crops in the United States. U.S. Department of Agriculture, Economic Research Service Rep 162. 60 p

Flockhart DTT, Pichancourt J-B, Norris DR, Martin TG (2015) Unravelling the annual cycle in a migratory animal: breedingseason habitat loss drives population declines of monarch butterflies. J Anim Ecol 84:155-165

Fuchsberg JR, Yong T-H, Losey JE, Carter ME, Hoffmann MP (2007) Evaluation of corn leaf aphid (Rhopalosiphum maidis, Homoptera: Aphididae) honeydew as a food source for the egg parasitoid Trichogramma ostriniae (Hymenoptera: Trichogrammatidae). Biol Control 40:230-236

Gagic V, Riggi LG, Ekbom B, Malsher G, Rusch A, Bommarco $R$ (2016) Interactive effects of pests increase seed yield. Ecol Evol. DOI: 10.1002/ece3.2003

Gallandt ER (2006) How can we target the weed seedbank? Weed Sci 54:588-596

Greiner R (2015) Factors influencing farmers' participation in contractual biodiversity conservation: a choice experiment with northern Australian pastoralists. Aust J Agric Res Econ 60:1-21

Hartzler RG (2010) Reduction in common milkweed (Asclepias syriaca) occurrence in Iowa cropland from 1999 to 2009. Crop Prot 29:1542-1544

Hartzler RG, Buhler DD (2000) Occurrence of common milkweed (Asclepias syriaca) in cropland and adjacent areas. Crop Prot 19:363-366

Heap I (2016) The International Survey of Herbicide Resistant Weeds. http://www.weedscience.org/. Accessed April 1, 2016

Herbert LH, Vazquez DE, Arenas A, Farina WM (2014) Effects of field-realistic doses of glyphosate on honeybee appetitive behaviour. J Exp Biol 217:3457-3464
Hoffmann MP, Pitcher SA, Cheever SA, Gardner J, Losey JE, Kuhar TP, Laub CA, Youngman RR (2006) Efficacy of inoculative releases of Trichogramma ostriniae (Hymenoptera: Trichogrammatidae) against European corn borer Ostrinia nubilalis (Lepidoptera: Crambidae) in field corn. Biol Control 36:345-349

Hoffmann MP, Walker DL, Shelton AM (1995) Biology of Trichogramma ostriniae (Hym.: Trichogrammatidae) reared on Ostrinia nubilalis (Lep.: Pyralidae) and survey for additional hosts. Entomophaga 40:387-402

Hoffmann MP, Wright MG, Pitcher SA, Gardner J (2002) Inoculative releases of Trichogramma ostriniae for suppression of Ostrinia nubilalis (European corn borer) in sweet corn: field biology and population dynamics. Biol Control 25:249-258

Holst E (2016) Farmers Key to Bringing Monarch Butterflies Back from the Brink of Extinction. http://ecowatch.com/ 2016/02/16/monarch-butterflies-brink-of-extinction/. Accessed February 25, 2016

Honey-Rosés J (2009) Disentangling the proximate factors of deforestation: the case of the monarch butterfly Biosphere Reserve in Mexico. Land Degrad Dev 20:22-32

Howard E, Davis AK (2015) Investigating long-term changes in the spring migration of monarch butterflies (Lepidoptera: Nymphalidae) using 18 years of data from Journey North, a Citizen Science Program. Ann Entomol Soc Am 108:664-669

Hutchison WD, Burkness EC, Mitchell PD, Moon RD, Leslie TW, Fleischer SJ, Abrahamson M, Hamilton KL, Steffey KL, Gray ME, Hellmich RL, Kaster LV, Hunt TE, Wright RJ, Pecinovsky K, Rabaey TL, Flood BR, Raun ES (2010) Areawide suppression of European corn borer with Bt maize reaps savings to non-Bt maize growers. Science 330:222-225

Inamine H, Ellner SP, Springer JP, Agrawal AA (2016) Linking the continental migratory cycle of the monarch butterfly to understand its population decline. Oikos. DOI: 10.1111/oik. 03196

Iowa State University (2013) The European Corn Borer Second Generation. http://www.ent.iastate.edu/pest/cornborer/ manage/second. Accessed March 17, 2016

Jensen B, Liesch PJ, Nice G, Renz M, Smith D (2015) Pest Management in Wisconsin Field Crops, 2016. Madison, WI: University of Wisconsin-Extension. $260 \mathrm{p}$

Jordan N, Vatovec C (2004) Agroecological benefits from weeds. Pages 137-158 in Inderjit, ed. Weed Biology and Management. Dordrecht, Netherlands: Springer

Jordan NR, Zhang J, Huerd S (2000) Arbuscular-mycorrhizal fungi: potential roles in weed management. Weed Res 40:397410

Kadrmas T, Johnson WS, Eiswerth M, Coca M (2003) The Estimated Costs of Treating Invasive Weeds in Elko County, Nevada. Reno, NV: University of Nevada Fact Sheet-03-41

Kogan M (1998) Integrated pest management: historical perspectives and contemporary developments. Annu Rev Entomol 43:243-270

Langpap C (2006) Conservation of endangered species: can incentives work for private landowners? Ecol Econ 57:558572

Lee JJ (2015) Imperiled Monarch Butterflies Get \$3.2 Million From U.S. Government. http://news.nationalgeographic.com/ news/2015/02/150209-monarch-butterfly-milkweed-habitatconservation-insect-science/. Accessed March 17, 2016

Li L-Y (1994) Worldwide use of Trichogramma for biological control on different crops: A survey. Pages 37-53 in Wajnberg 
E, Hassan SA, eds. Biological Control with Egg Parasitoids. Wallingford, UK: CAB International

Lindquist, JL, Mortensen DA, Clay SA, Schmenk R, Kells JJ, Howatt K, Westra P (1996) Stability of corn (Zea mays)velvetleaf (Abutilon theophrasti) interference relationships. Weed Sci 44:309-313

Lindquist, JL, Mortensen DA, Westra P, Lambert WJ, Bauman TT, Fausey JC, Kells JJ, Langton SJ, Harvey RG, Bussler BH, Banken K, Clay S, Forcella F (1999) Stability of corn (Zea mays)-foxtail (Setaria spp.) interference relationships. Weed Sci 47:195-200

Lingenfelter D, Curran WS (2015) Back to the future with nonGMO herbicide programs. Page 300 in Proceedings of the 55th Annual Meeting of the Weed Science Society of America. Champaign, IL: WSSA

Losey JE, Hufbauer RA, Hartzler RG (2003) Enumerating Lepidopteran species associated with maize as a first step in risk assessment in the USA. Environ Biosafety Res 2:247-261

Losey JE, Vaughan M (2006) The economic value of ecological services provided by insects. Bioscience 56:311-323

Loux MM, Doohan D, Dobbels AF, Johnson WG, Young BG, Legleiter TR, Hager A (2016) Weed Control Guide for Ohio, Indiana and Illinois. Columbus, $\mathrm{OH}$ : Ohio State University Extension Pub WS16/Bull 789/IL15. 224 p

Lucht JM (2015) Public acceptance of plant biotechnology and GM crops. Viruses (Basel) 7:4254-4281

Lundgren JG (2009) Nutritional aspects of non-prey foods in the life histories of predaceous Coccinellidae. Biol Control 51:294-305

Mason CE, Rice ME, Calvin DD, Van Duyn JW, Showers WB, Hutchison WD, Witkowski JF, Higgins RA, Onstad DW, Dively GP (1996) European Corn Borer: Ecology and Management. Ames, IA: Iowa State University, North Central Iowa Regional Extension Pub 327

Mohler CL, Marschner CA, Caldwell BA, DiTommaso A (2016) Weed mortality caused by row-crop cultivation in organic corn-soybean-spelt cropping systems. Weed Technol. DOI: 0.1614/WT-D-16-00020.1

Monsanto (2015) The Monarch Butterfly Commitment. http:// www.monsanto.com/improvingagriculture/pages/monarchbutterfly.aspx. Accessed March 15, 2016

Mortensen DA, Egan JF, Maxwell BD, Ryan MR, Smith RG (2012) Navigating a critical juncture for sustainable weed management. Bioscience 62:75-84

Moyer J (2011) Organic No-Till Farming. Austin, TX: Acres U.S.A. $204 \mathrm{p}$

Nagarkatti S, Tobin PC, Saunders MC, Muza AJ (2003) Release of native Trichogramma minutum to control grape berry moth. Can Entomol 135:589-598

Nalewaja JD (1999) Cultural practices for weed resistance management. Weed Technol 13:643-646

Neeser C, Dille JA, Krishnan G, Mortensen DA, Rawlinson JT, Martin AR, Bills LB (2004) WeedSOFT ${ }^{\circledR}$ : a weed management decision support system. Weed Sci 52:115-122

Norris RF, Kogan M (2000) Interactions between weeds, arthropod pests, and their natural enemies in managed ecosystems. Weed Sci 48:94-158

Oberhauser KS, Prysby MD, Mattila HR, Stanley-Horn DE, Sears MK, Dively G, Olson E, Pleasants JM, Lam W-KF, Hellmich RL (2001) Temporal and spatial overlap between monarch larvae and corn pollen. Proc Natl Acad Sci USA 98:11913-11918
Osteen, C, Gottlieb J, Vasavada U, eds(2012) Agricultural Resources and Environmental Indicators, 2012. Washington, DC: U.S. Department of Agriculture, Economic Research Service EIB-98

Palumbi SR (2001) Humans as the world's greatest evolutionary force. Science 293:1786-1790

Park MG, Blitzer EJ, Gibbs J, Losey JE, Danforth BN (2015) Negative effects of pesticides on wild bee communities can be buffered by landscape context. Proc R Soc Lond B Biol Sci 282:20150299

Pleasants JM (2015) Monarch butterflies and agriculture. Pages 169-178 in Oberhauser KS, Nail KR, Altizer SM, eds. Monarchs in a Changing World: Biology and Conservation of an Iconic Insect. Ithaca, NY: Cornell University Press

Pleasants JM, Oberhauser KS (2012) Milkweed loss in agricultural fields because of herbicide use: effect on the monarch butterfly population. Insect Conserv Divers 6:135144

Pleasants JM, Williams EH, Brower LP, Oberhauser KS, Taylor OR (2016) Conclusion of no decline in summer monarch population not supported. Ann Entomol Soc Am 109:169171

Prather T, DiTomaso J, Holt J (2000) Herbicide Resistance: Definition and Management Strategies. Davis, CA: University of California, Division of Agriculture and Natural Resources Pub 8012. $14 \mathrm{p}$

Preston C, Powles SB (2002) Evolution of herbicide resistance in weeds: initial frequency of target site-based resistance to acetolactate synthase-inhibiting herbicides in Lolium rigidum. Heredity 88:8-13

Pretty JN, Brett C, Gee D, Hine RE, Mason CF, Morison JIL, Raven H, Rayment MD, van der Bijl G (2000) An assessment of the total external costs of UK agriculture. Agric Syst 65:113-136

Russell K, Bessin R (2009) Integration of Trichogramma ostriniae releases and habitat modification for suppression of European corn borer (Ostrinia nubilalis Hübner) in bell peppers. Renew Agric Food Syst 24:19-24

Ryan MR, Mortensen DA, Seidel R, Smith RG, Grantham AM (2009) Weed community response to no-tillage practices in organic and conventional corn. Proc Northeast Weed Sci Soc 63:94

Ryan MR, Smith RG, Mirsky SB, Mortensen DA, Seidel R (2010) Management filters and species traits: weed community assembly in long-term organic and conventional systems. Weed Sci 58:265-277

Sarajlić A, Raspudi E, Maji I, Ivezi M, Brme M, Josipovi M (2014) Efficacy of natural population of Trichogramma wasps against European corn borer in field maize. Poljoprivreda 20:18-22

SAS (2012) JMP Statistical Software. Cary, NC: SAS Institute, Inc

Semmens BX, Semmens DJ, Thogmartin WE, Wiederholt R, López-Hoffman L, Diffendorfer JE, Pleasants JM, Oberhauser KS, Taylor OR (2016) Quasi-extinction risk and population targets for the eastern, migratory population of monarch butterflies (Danaus plexippus). Sci Rep 6:23265

Shaner DL, Lindenmeyer RB, Ostlie MH (2012) What have the mechanisms of resistance to glyphosate taught us? Pest Manag Sci 68:3-9

Shelton AM Zhao, J-Z, Roush RT (2002) Economic, ecological, food safety, and social consequences of the deployment of $\mathrm{Bt}$ transgenic plants. Annu Rev Entomol 47:845-881

DiTommaso et al.: Integration of pest control • 755 
Siegfried BD, Hellmich RL (2012) Understanding successful resistance management. GM Crops Food 3:184-193

Smith EA, DiTommaso A, Fuchs M, Shelton AM, Nault BA (2011) Weed hosts for onion thrips (Thysanoptera: Thripidae) and their potential role in the epidemiology of iris yellow spot virus in an onion ecosystem. Environ Entomol 40:194-203

Smith RA, Mooney KA, Agrawal AA (2008) Coexistence of three specialist aphids on common milkweed, Asclepias syriaca. Ecology 89:2187-2196

Smith SM (1996) Biological control with Trichogramma: advances, successes, and potential of their use. Annu Rev Entomol 41:375-406

Srinivasan R, Alvarez JM, Bosque-Pérez NA, Eigenbrode SD, Novy RG (2008) Effect of an alternate weed host, hairy nightshade, Solanum sarrachoides, on the biology of the two most important potato leafroll virus (Luteoviridae: Polerovirus) vectors, Myzus persicae and Macrosiphum euphorbiae (Aphididae: Homoptera). Environ Entomol 37:592-600

State Symbols USA (2016) List of State Insects. http://www. statesymbolsusa.org/categories/insect. Accessed March 17, 2016

Stephens EJ, Losey JE, Allee LL, DiTommaso A, Bodner C, Breyre A (2012) The impact of Cry3Bb Bt-maize on two guilds of beneficial beetles. Agric Ecosyst Environ 156:72-81

Stern VM, Smith RF, van den Bosch R, Hagen KS (1959) The integration of chemical and biological control of the spotted alfalfa aphid: the integrated control concept. Hilgardia 29:81101

Sturz AV, Matheson BG, Arsenault W, Kimpinski J, Christie BR (2001) Weeds as a source of plant growth promoting rhizobacteria in agricultural soils. Can J Microbiol 47:10131024

Taleb NN (2007) The Black Swan: The Impact of the Highly Improbable. New York: Random House. 366 p

Timmons FL (1970) A history of weed control in the United States and Canada. Weed Sci 18:294-307

Treacy MF, Benedict JH, Walmsley MH, Lopez JD, Morrison RK (1987) Parasitism of bollworm (Lepidoptera: Noctuidae) eggs on nectaried and nectariless cotton. Environ Entomol 16:420-423

[USDA, APHIS] U.S. Department of Agriculture, Animal and Plant Health Inspection Service (2015) Monsanto Co.; determination of nonregulated status of herbicide resistant soybean and cotton. Fed Regist 80:2675-2676

[USDA NASS] U.S. Department of Agriculture, National Agricultural Statistics Service (2015) Acreage. http://usda. mannlib.cornell.edu/MannUsda/viewDocumentInfo.do? documentID=1000. Accessed March 17, 2016

[USDA NASS] U.S. Department of Agriculture, National Agricultural Statistics Service (2016) http://usda.mannlib. cornell.edu/usda/current/Acre/Acre-06-30-2016.pdf. Accessed July 27, 2016

[USDA NRCS] U.S. Department of Agriculture National Resources Conservation Service (2015) The PLANTS Database. http://plants.usda.gov/index.html. Accessed February 25, 2015

[USDI] U.S. Department of the Interior (2014) Endangered and threatened wildlife and plants; 90-day findings on two petitions. Fed Regist 79:78775-78778 (to be codified at 50 CFR pt. 17)

[USDI] U.S. Department of the Interior (2015) Endangered and threatened wildlife and plants; 12 -month finding on a petition to list greater sage-grouse (Centrocercus urophasianus) as an endangered or threatened species. Fed Regist 80:59858-59942 (to be codified at $50 \mathrm{CFR}$ pt. 17)

Vencill WK, Nichols RL, Webster TM, Soteres JK, MallorySmith C, Burgos NR, Johnson WG, McClelland MR (2012) Herbicide resistance: towards an understanding of resistance development and the impact of herbicide-resistant crops. Weed Sci 60(special issue):2-30

Warwick SI, Black LD (1988) The biology of Canadian weeds, 90: Abutilon theophrasti. Can J Plant Sci 68:1069-1085

Waterfield G, Zilberman D (2012) Pest management in food systems: An economic perspective. Annu Rev Environ Resour 37:223-245

Westerman PR, Liebman M, Menalled FD, Heggenstaller AH, Hartzler RG, Dixon PM (2005) Are many little hammers effective? velvetleaf (Abutilon theophrasti) population dynamics in two- and four-year crop rotation systems. Weed Sci 53:382-392

Wilson RS, Tucker MA, Hooker NH, LeJeune JT, Doohan D (2008) Perceptions and beliefs about weed management: perspectives of Ohio grain and produce farmers. Weed Technol 22:339-350

World Wildlife Fund (2016) Survey Suggests Migratory Monarchs Are Rebounding-With a Long Road Ahead. https://www.worldwildlife.org/stories/survey-suggestsmigratory-monarchs-are-rebounding-with-a-long-road-ahead. Accessed June 2, 2016

Wressell HB (1973) The role of parasites in the control of the European corn borer, Ostrinia nubilalis (Lepidoptera: Pyralidae), in southwestern Ontario. Can Entomol 105:553-557

Yarrow G (2009) Rules, Regulations and Laws Affecting Wildlife Management. Clemson, SC: Clemson Extension Fact Sheet 26. $8 \mathrm{p}$

Yenish JP, Durgan BR, Miller DW, Wyse DL (1997a) Wheat (Triticum aestivum) yield reduction from common milkweed (Asclepias syriaca) competition. Weed Sci 45:127-131

Yenish JP, Fry TA, Durgan BR, Wyse DL (1996) Tillage effects on seed distribution and common milkweed (Asclepias syriaca) establishment. Weed Sci 44:815-820

Yenish JP, Fry TA, Durgan BR Wyse, DL (1997b) Establishment of common milkweed (Asclepias syriaca) in corn, soybean, and wheat. Weed Sci 45:44-53

Zandstra BH, Motooka PS (1978) Beneficial effects of weeds in pest management-a review. PANS Pest Artic News Summ 24:333-338

Zhang F, Baberdreier D, Wang Z-Y, Il KS, Zhang L, Pyon YC, Bai S-X, Song K, Ri JO, Grossrieder M, Kuhlmann U (2010) Mass releases of Trichogramma ostriniae increase maize production in DPR Korea. J Appl Entomol 134:481-490

Zimdahl RL (2004) Weed-Crop Competition: A Review. 2nded.Oxford, UK: Blackwell Publishing Ltd. 220 p

Ziska LH, Dukes JS (2010) Benefits from weeds. Pages 181-197 in Weed Biology and Climate Change. Hoboken, NJ: WileyBlackwell

Received April 4, 2016, and approved July 6, 2016.

Associate editor for this paper: John L. Lindquist, University of Nebraska. 